\title{
Error Analysis On The Use Of Past Tense In Writing Recount Text A Case Study At The Second Year Students Of Madrasah Tsanawiyah Darul Ishlah Ireng Lauq At The Academic Year 2013/2014
}

\author{
Suparlan \\ Institut Pendidikan Nusantara Global, Jalan Raya Praya-Mantang Km-07 Aik Mual, \\ Lombok Tengah-NTB, 83511 \\ Suparlan@nusantaraglobal.ac.id
}

\begin{abstract}
The writer is interested in investigating the error analysis in using past tense in writing recount text a case study at the second year students of Madrasah Tsanawiyah Darul Ishlah Ireng Lauq at the academic year 2013/2014. The problem of the present study is limited in on the use of past tense in writing recount text. On the other hand, the general objective of the writing is to analyze the use of past tense in writing recount text. The specific objective is to know the students ability in using the past tense especially in writing recount text. The population of the study includes all students who have been studying at the second year of Madrasah Tsanawiyah Darul Ishlah Ireng Lauq at the academic year 2013/2014. The instrument of data collection is only one test. The test typel part namely slot test. The test is confined to use the simple past tense. The data is analyzed by descriptive quantitative method. From the result of this analyze, the writer concludes the second year of the students of Madrasah Tsanawiyah Darul Ishlah Ireng Lauq at the academic year 2013/ 2014 has difficulty in identifying the past tense. This analyze shown that they make errors in using auxiliary did, errors in using verbs and other errors. Finally not only auxiliary did or verb as the specific study had most errors but also another errors appear without they realize, it happened because the lack of mastery in structure of past tense one of the tense in English.
\end{abstract}

Keywords: Error, Simple past tense and Recount text

\section{INTRODUCTION}

For many years, English has been the most important foreign language in Indonesia, which is though from elementary school to university. However, in senior high school, English is though as main Subject in which the government has changed the curriculum into curriculum based on competence 2004 .

According to Departemen Pendidikan nasional (2003; 36) "The competence-basing language curriculum is systematic draft and strategy which build the communicative competence or the competence of contextual. It means that it builds all the basis of competence themselves. They are like Linguistic Competences, social culture and strategies to make the benefit context.

From the statement above, it is clear that the curriculum based on competence 2004 tries to develop and achieve the communicative competence or discourse competence and has perspective that is comprehensive to the discourse. The learner must be to master the four skills, they are: listening, speaking, reading and writing, also English components such as: grammar, vocabulary, pronunciation, etc.

Nunan (1989:35) points out, "It has been argued that learning to write fluently and expressively is the most difficult of the macro skills for all language users regardless of whether the language in question is first, second or foreign language." Another opinion comes from Heaton (1989: 138). He explain that the writing skills are complex and sometimes difficult to teach, requiring mastery not only of grammatical and rhetorical devices but also of conceptual and judgment elements. It means that ability to write need a special skill and process in organizing language material by using learners ${ }^{e e}$ own words and ideas and to be good composition.

According to the results of the study done by the students of IKIP Budi Utomo Malang show that in learning English, most of the students find the 
difficulties, especially in applying grammar in their speaking and writing. So, they will make mistakes and errors. It describes that learners' ability in English is still poor and they need to be though more effectively.

The learners ${ }^{\text {ee }}$ often make mistakes end even errors in learning English, especially when they try to arrange sentences or use tenses in their writing. As a result, they will write sentences ungrammatically. Actually ungrammatical sentences have great influence when the learners are writing sentences. That can be influenced by the first language which is different from the second language in written form. Therefore, the first language can interfere learners in the process of the second language. Abort (1981: 216) wrote.

"For pedagogic purposes, teachers and others more likely to be concerned with the performances of whole groups and especially with problems they have in commons. For these purposes, we need to ensure that the data comes from fairly homogenous groups as regards mother tongue, age, previous teaching, and if possible, intelligence. Perhaps the most important of these factors is the mother tongue, particularly if phonological errors are being studied.

From the statement above, it can be seen that errors in learning a second language are caused by the interference of the learners' mother tongue. In other words, errors made by the learners sometimes caused by use of the first language.

Making errors are a natural and unavoidable part of the process of learning

English. Many kinds of errors arise when the learners write because they do not master the English structure well. Also, errors are inability of the students in using rules of the components and elements of the second language. Brown (1987: 170)

said that "second language learning is a process that is clearly not unlike first language learning in its trial and errors nature". It means that the learners cannot avoid errors in learning second language. That statement is supported by Wigant (2000: 11).

"Many linguist and researcher have found out that learners' errors may

account the process of learning a target language in other words, making errors is considered to be natural to the learners. More extremely, they hypothesize that errors should not be viewed as problems tobe overcome but, rather as normal and inevitable features indicating the strategies that learner use".

So almost all learners must make errors when they are learning English because it is difficult to separate error in the process of learning English. Students' errors are very useful ways of showing what they have and have not learnt. Dubin F. and Olshtain E. (1986: 74) reported,:..., today errors are viewed as integral part of the language-learning process from which we can gain very significant insight.

"It tells that errors are important to study in order to understand the process of learning. A study of learners' errors are describes what problems the learners are having now and help the teacher to plan the remedial work. In addition, the teacher should not see negatively as a sign of failure but see them positively as an indication of what the teacher still need to teach. So, if the teacher tries to prevent students' errors, he/she never finds out what they do not know.

There are four standard competences in curriculum based in competences curriculum based on competence 2004. One of them is writing. In writing students

are hoped to be able to express many written meaning that have purposes in communicative, text structure, etc. They can develop their writing in the forms of genre (kind of text) such as: narrative, descriptive, recount, news items, etc as a

means of communications.

One of genres is recount. Recount is tells something happening in the past time, like: history, journey, autobiography, biography, diary, personal letter, etc.

As it tells some events, it usually uses sequences word, such as: when, while, after, before, until, etc. Then tense uses in recount text is simple past tense, because it tells past events.

There are several studies in line with this research. First, It was conducted by Sovia 
Herlina (2010) which entitled "Error analysis on the use of past tense in writing recount text a case study of the third grade students at SMPN 3 Tanjung. This Study repeated that the students failed to use verb in the past form. There were many students used verb I in their writing. Second, In addition Ni Luh Nining Astiti Prami using the title an analysis on the use of past tense in writing recount text at the Second Grade Students at the First Semester of SMPN 23 Mataram, in Academic Year 2010/2011. That the students still had problem in recognized past form and the difference between past form and verb I.

To make a good composition, the students must be able to master and apply the structure correctly, especially about tense used. In this case, the tense used is simple past tense. If they cannot do that, of course, errors will arise.

Automatically their writing will cause misunderstanding for the readers, because

the readers cannot receive the massage or expression of their idea well. Most of the students still find problems in using it, because of their limited mastery, especially the differences between regular and irregular verb. Therefore the writer wants to analyze the errors made by the students and tries to give solutions to overcome their problems. He chooses the title "Error Analysis on the Use of Past Tense in Writing Recount Text, A Case Study At The second Year Students of Maderasah Tsanawiyah Darul Ishlah Ireng Lauq at the Academic Year 2013/2014."

\subsection{Statement of the Problem}

To make a Systematic Approach in solving the problem, the writer formulates the Research question as follow:

-What types of error in the linguistic categories made by the student on the use of past tense in writing recount text?

\subsection{Purpose of the Study}

Based on the problem statement above, the purpose of the study is:

- To find out the types of error in the linguistic categories made by the student on the use of past tense in writing recount text.

\subsection{Scope of the Study}

The writer does not observe the whole student of the Madrasah Tsanawiyah Darul Ishlah Ireng Lauq, but the writer limits on the second year students at the academic year 2013/2014 those are chosen to be samples are underplayed by the two considerations.

1.4.1 They have been learning about tenses/ grammar that given since the first semester.

1.4.2 They have been learning about writing that given since the first semester. Another reason is that grammar about tenses is very complex, to explain and search the whole part of it. This study focused on past tense. The whole subject tenses and writing have explained and discussed about past tense it details and clearly. It is hoped that the learners are able to recognize and identify.

\subsection{Significance of the Study}

The writing will be of some used to:

1.5.1 Help the learners of English to write correct English sentence as step of creating writing skill.

1.5.2 Present a creative situation of writing skill to the learner of English.

1.5.3 Motive English teacher to apply practical techniques in teaching English in order to describe interference.

1.5.4 Ask English teachers to be more attention and to understand to the learners, errors and to overcome them if it is possible.

1.5.5 The result of this study will encourage them to improve their competence in writing form well.

\subsection{Definition of the Key Term}

A task is work plan that requires learners to process language pragmatically in order to achieve an outcome that can be evaluated in term whether the correct or appropriate propositional content has been conveyed To avoid misunderstanding and misinterpretation in this research, some terms are defined as follows: 1.6.1 Writing ability

Writing ability is an activity to produce a sequence of sentences arranged in a particular order and linked together in certain ways, (Byrne, 1979). In this study, writing refers to the writing that involves the encoding of the message produce a sequence of sentence by using combination of letter.

1.6.2 Recount text 
A recount text is a kind of text that functions to retell events for purpose of informing or entertaining.

\subsubsection{Past tense}

The past tense is a grammatical tense whose principal function is to place an action or situation in past time.

\section{RESEARCH METHODS}

\subsection{Research Participant}

This research conducted at Madrasah Tsanawiyah Darul Ishlah Ireng Lauq located on Jl. Raya Ireng, Dusun Ireng Lauq, Desa Jatisela, Kec. Gunung Sari. 83351. The total number of the classrooms of this school was 3 classes. The third grade consists of 1 classroom. The first grade consists of 45 students, and the second grade consists of 45 students, and third grade consists of 15 students. So the total students are 105 students.

The subject of the research was the second year students from class II A and class II B of Madrasah Tsanawiyah Darul Ishlah at the academic year 2013/2014 and each classes consists of 23 (twenty three) and 22 (twenty two) students. So the total subjects were 45 students. They chosen as the subjects of the research based on the following reasons: First reason is the second year students had difficulties finding ideas to write Recount text. Second reason is the second year students had difficulties organizing their ideas. Third reason is there were many errors on the use of past tense in writing Recount text. The fourth reason is the students had low motivation since the writing activities were not varied and interesting.

\subsection{Population and Sampling Technique}

\subsubsection{Population}

The population was the second year students of Madrasah Tsanawiyah Darul Ishlah at the academic year 2013/2014. The second year students are divided into two classes, IIA to IIB and each classes consists of 23 (twenty three) and 22 (twenty two) students. So, the total is about 45 (fourty five) students.

\subsubsection{Sampling technique}

When an investigator toke random sampling it is representative to selects a sampling which consist of $100 \%$ from population (Arikunto, 1986: 19) the writer used such a kind of sampling technique. Especially simple random sampling because the subject of this case they were in the same level of ability or English mastery.

The writer draws 45 (forty five) students as sample about $100 \%$ as states in no. 1 above the sample is drawn from class IIA to IIB and each class contributes is 23 (twenty three) and 22 (twenty two) students such obtain presentation of errors. The sample is only one groups and all of them consists of 45 students who get testing random sampling. The writer used lottery in order to avoid the subjective sense.

The procedure applied for random sampling are: 2.2.2.1 Listening all the members of the population

2.2.2.2 Giving codes in the form of member to each subject

2.2.2.3 Writing the codes in small piece of paper

2.2.2.4 Rolling or folding the paper

2.2.2.5 Putting the folded paper into a can

2.2.2.6 Shaking the can

2.2.2.7 Taking the folded paper as many as needed.

\subsubsection{Method of Collecting Data}

A data collection was very important step in scientific research because the data used to test hypothesis. The thesis test was slot test. Slot test requires the students to slot are scattered word of English the word are constructed word in the blank of sentence. The test aims to find errors on auxiliary did and verb errors. The Thesis tests number consist of 10 .

The test is made by the writer himself. It is supposed to be valid. Especially content validity since the materials inserts are taken from "The teaching programs" of English for second class of Madrasah Tsanawiyah Darul Ishlah Ireng Lauq.

\subsubsection{Try Out Of the Test}

The purpose of conducting the try out test is to get information concerning the characteristics of the test with an emphasis on its reliability. The try out is conducted in second year students as the place of conducting the try out is that they consider that, they have the same ability of mastering structure as the third semester, 
because the second year student have got writing in the first year. So the writer assumes that they have same level of ability mainly in understanding the English writing especially past tense form.

\subsection{Data Analysis Procedure}

This study was aimed at finding out the used past tenses by students, the data was obtained by making table that had arrange from past tense test was presented one type of instrument in one table to be analyzed on use of past tense, to analyze the data the writer used descriptive analysis to find the percentage of the students ability in the use of past tense in writing recount text. Then the percentage of the test was determined with the formula:

$\mathrm{Pfi} / \mathrm{d} / \mathrm{a} / \mathrm{u}=\frac{\sum \mathrm{fi} / \mathrm{d} / \mathrm{a} / \mathrm{u}}{\sum f i+\sum f d+\sum f a+\sum f u}$

Pfi/d/a/u = Percentage of to be (i) Verb (d), Another Error (a) or Total Error (u)

$\sum \mathrm{fd} \quad=$ Total frequency of verb

$\sum \mathrm{fa}=$ Total frequency of another error

$\sum \mathrm{fu}=$ Total frequency of Total error

\section{RESEARCH FINDING}

\subsection{Research Finding}

Errors percentage is useful to determine some possible main learning. Strategies applied by the language learner to grasp in the target language. These are indicated qualitative percentage if the percentages are:

3.1.1. $76-100 \%$ is excellent

3.1.2. $56-75 \%$ is good

3.1.3. $40-55 \%$ is moderate

3.1.4. $0-40 \%$ is mean less then forty is low

Before the writer analyzes toward the data obtained, it is necessary to keep on mind that the procedure in finding the data is through one item in one packet. The item was through slot test. This test is taken out to measure the students' ability in using pat tense in writing recount text, and it is provided into the table and also to make the writer easy to the analysis on the students' error of using past tense.

The writer present the following table to explain the errors numbers of the test "out line".

Table 4.1 the result of students test

$$
\text { Number of Error }
$$

\begin{tabular}{|l|l|l|l|l|l|}
\hline No & Subject's & Aux & Verb & Other & Total \\
& Name & Did & & Errors & \\
\hline 1 & 2 & 3 & 4 & 5 & 6 \\
\hline 1 & F & - & - & - & 0 \\
2 & WP & 1 & 5 & - & 6 \\
3 & I & 1 & 4 & 2 & 7 \\
4 & F & - & 3 & 1 & 4 \\
5 & FS & - & 1 & - & 1 \\
6 & ATH & 1 & 5 & 2 & 8 \\
7 & WF & - & 1 & 3 & 4 \\
8 & DAD & - & 3 & 1 & 4 \\
9 & FS & 1 & 4 & 1 & 6 \\
10 & R & - & 3 & 2 & 5 \\
11 & SH & - & 3 & - & 3 \\
12 & HM & - & - & 2 & 2 \\
13 & D & - & 3 & 1 & 4 \\
14 & IH & - & - & 1 & 1 \\
15 & LF & 1 & 4 & 1 & 6 \\
16 & M & 1 & 6 & 2 & 9 \\
17 & MLH & 1 & 3 & 1 & 5 \\
18 & SH & - & 4 & - & 4 \\
19 & MH & 1 & 4 & 1 & 6 \\
20 & NRH & 1 & 6 & 1 & 8 \\
21 & FI & 1 & 3 & 1 & 5 \\
22 & MAF & - & 1 & 2 & 3 \\
23 & H & - & 2 & 1 & 3 \\
24 & S & 1 & 3 & 1 & 5 \\
25 & WS & 1 & 1 & - & 2 \\
26 & AH & 1 & 5 & 1 & 7 \\
27 & EA & - & 3 & 2 & 5 \\
28 & EH & 1 & 5 & 2 & 8 \\
29 & FI & - & 4 & - & 4 \\
30 & HI & - & 6 & 2 & 8 \\
31 & HR & 1 & 2 & - & 3 \\
32 & J & - & 1 & 1 & 2 \\
33 & MI & - & 7 & 2 & 9 \\
34 & SU & 1 & 3 & 1 & 5 \\
35 & MES & 1 & 3 & 1 & 5 \\
36 & Y & 1 & 2 & 1 & 4 \\
37 & SB & - & 4 & 1 & 5 \\
38 & SN & 1 & 5 & - & 6 \\
39 & PR & - & 3 & - & 3 \\
40 & Z & - & 3 & 1 & 4 \\
41 & RA & - & - & - & 0 \\
42 & MJ & 1 & 4 & 1 & 6 \\
43 & SR & - & 6 & 2 & 8 \\
45 & M & - & 5 & 1 & 6 \\
\hline & & 1 & 3 & 1 & 5 \\
\hline & & & & & 214 \\
\hline
\end{tabular}




\begin{tabular}{|l|l|l|l|l|}
\hline Percentage & 9,81 & 68,22 & 21,96 & \\
\hline
\end{tabular}


To be able to determine the errors percentage, it is worth considering the frequencies of errors making in appendix above. From appendix above, we can identify that the total frequency of Auxiliary did, verb and other errors is 214 respectively. It errors making are:

The percentage of Auxiliary did error is:

$$
\begin{array}{rl}
\mathrm{P}=\mathrm{X} & 100 \% \\
& =\mathrm{x} 100 \% \\
& =9,81 \%
\end{array}
$$

The percentage of Verb error is:

$$
\begin{array}{rl}
P=X & 100 \% \\
& =\times 100 \% \\
& =68,22 \%
\end{array}
$$

\section{CONCLUSION}

In learning English structure, sometimes the learner finds the problem of difficulty in understanding it. It is understandable because learning it involves structure (change of verb, word order, tense etc) of the language. Moreover the learning itself is complicated, it involves many things, many factors influence its process, for example talent, intelligence, motivation, etc. So learning language is foreign language in Indonesia. Naturally it is quite different from Indonesia.

Based on the discussion on the chapter four, the preceding chapter has already shown that:

The writer concludes that the second year students of Madrasah tsanawiyah Darul Ishlah Ireng Lauq in academic year 2013/2014 have difficulty in identifying the past tense. This study shown that they make errors most on verb errors. Finally not only 20 students made error in using auxiliary did, but also there were 41 students made error in using verb. The specific study had most errors but also another errors appear without they realize, it happened because the lack of mastery in structure of past tense one of the tense in English.

\section{ACKNOWLEDGEMENT}

Dear all of my supporters such as my beloved wife Sulmiatun, my close friend Jumadil, M.Pd., my parents on east and north part of Lombok, all of my friends, good supporter Mr. Per and wife, my children and so on. I would like to thank all of you who supported me in writing this journal.

\section{REFFERENCES}

Apriana, Aricha, 2008. Descriptive study on teacher' feedback in writing II Course. An Unpublished Thesis of Sarjana Degree in English Education. FKIP Universitas Mataram.

Aqib, Zainal. 2006. Penelitian Tindakan Kelas. Bandung: Yrama Widya.

Ariffudin. 2007. A Task Based Paragraph Development. Mataram. Universitas Mataram.

Arikunto, S. 1991. Prosedur penelitian suatu pendekatan praktis. Jakarta: PT. Bina Aksara.

Brown, Douglas. H. (2002). Teaching by principle and interactive approach to language pedagogy. Second edition.

Budiman S.L. (2010). Common problem face by students in writing recount texts. A case study at the first year students of senior high school at SMA 1 Terara in academic program 2009/2010. An unpublished Thesis of SI PBS FKIP Unram Matarm: UNRAM.

Byrne, D. 1988. Teaching Writing Skills. Longman Handbook for Language Teacher. Essex Longmn Group.

Depdiknas. (2003). Standar Kompetensi Bahasa Inggri.

Hafniah, Linda F. 2010. A Study on Students Ability in Writing Narrative Text. An Unpublished Thesis of Sarjana Degree in English Education. FKIP Universitas Mataram.

Halliday, M.A.K and Hasan, R. 1976. Cohesion in English. London: Longman Inc.

Heaton, J.B. 1975. Writing English Language Test: A Practical Guide for Teachers of 
English as Second or Foreign Language. Essex: Longman Group.

Horby, As. 1995. Oxford Advanced Learner Dictionary. Oxford University Press.

Ikra. 2007. Student' Lexico Grammatical Errors In Paragraph Writing: A case Study at Third Semester Students of English Department University of Mataram Academic Year 2006-2007. An Unpublished Thesis of Sarjana Degree at FKIP UNRAM, Mataram: FKIP UNRAM. 